\title{
Alveolar macrophage-induced suppression of peripheral blood mononuclear cell responsiveness is reversed by in vitro allergen exposure in bronchial asthma
}

\author{
M.A. Spiteri*, R.A. Knight+, J.Y. Jeremy**, P.J. Barnes ${ }^{+}$, K.F. Chung ${ }^{+}$
}

Alveolar macrophage-induced suppression of peripheral blood mononuclear cell responsiveness is reversed by in vitro allergen exposure in bronchial asthma. M.A. Spiteri, R.A. Knight, J.Y. Jeremy, P.J. Barnes, K.F. Chung. CERS Journals Ltd 1994.

ABSTRACT: Little information is available on the specific role of alveolar macrophages (AMs) in modulating local cellular reactions to inhaled allergens in atopic asthma.

We investigated the influence of alveolar macrophages obtained by bronchoalveolar lavage (BAL) on the proliferative responses of lavage and peripheral lymphocytes from 12 patients with atopic asthma, 6 nonasthmatic symptomatic atopic subjects, and 6 nonatopic normal volunteers, in the context of in vitro exposure to relevant and nonrelevant allergens.

Fresh nonadherent bronchoalveolar lavage cells from atopic asthmatic patients, depleted of alveolar macrophages, proliferated spontaneously more than nonadherent bronchoalveolar lavage cells from normal subjects. Addition of autologous asthmatic alveolar macrophages reduced this endogenous "activation". Asthmatic and normal alveolar macrophages also inhibited phytohaemagglutinin-stimulated proliferation of both autologous and allogeneic nonadherent peripheral blood mononuclear cells (PBMC). In contrast, autologous asthmatic alveolar macrophages induced strong proliferation of peripheral blood mononuclear cells when stimulated with allergen to which the patient was skin test and radio allergosorbent test (RAST) reactive; however, no response was seen with allergens to which the patient was insensitive. No such allergen-specific proliferation was seen with alveolar macrophages from nonasthmatic atopic subjects.

These data support the presence of functionally-active alveolar macrophages within the airways of atopic asthmatic patients, that under normal stable conditions suppress the induction of peripheral blood mononuclear cell responses, and which only on contact with specific allergen appear to switch to inducer alveolar macrophages, with consequent peripheral blood mononuclear cell hyperactivation.

Eur Respir J., 1994, 7, 1431-1438.
*Dept of Respiratory Medicine, Keele University, Stoke-on-Trent, UK. +The National Heart \& Lung Institute, London, UK. **Dept of Chemical Pathology, Royal Free Hospital, London, UK.

Correspondence: M.A. Spiteri

Lung Cell Biology Group

School of Postgraduate Medicine

Keele University

Medical Research Laboratories

Hartshill Road

Hartshill

Stoke-on-Trent ST4 7NY

UK

Keywords: Alveolar macrophages asthma

peripheral blood mononuclear cell suppression

relevant allergen

reversal

Received: June 221993

Accepted after revision April 181994

This work was supported by the T.V. James Fellowship (1990) from the British Medical Association to M. Spiteri.
Atopic asthma results from inappropriate cellular immune reactions to nonpathogenic airborne allergens [1]. A multistage inflammatory response develops within the airway, together with the release of biologically active mediators [2-4], and secondary pathological changes in the mucosa [5]. Whilst recognizing the importance of the T-cell system in specific allergen recognition, the critical regulation of these events in allergic asthma may depend on the alveolar macrophage (AM).

The AM has been observed to be involved in a dichotomy of roles in its defence of the local microenvironment. This versatile character allows the macrophage to process inhaled allergen, which it then presents in a "modified and recognizable" form to primed Tlymphocytes $[6,7]$. Consequently, the macrophage itself becomes the target of a positive feedback loop through the production of macrophage-activation lymphokines, which heighten its capacity to terminate the offending stimulus [8]. In addition, the AM may also act as a store of allergen through its ability to endocytose, and then return allergen to its surface. The AM therefore possesses the requisite properties for the initiation and prolongation of an allergic and inflammatory reaction, such as bronchial asthma $[9,10]$.

The question arises as to whether AMs can determine the fate of allergen-driven T-cell activation in asthma. Mounting evidence supports the notion that AMs under steady-state conditions can exert a protective effect on the local milieu by preventing an immunological overreaction to the large amounts of inhaled antigens [11]. Recently, it was shown that the functional capacity of the AM is such that it can regulate the induction and 
strength of acquired T-cell responses in the human lung. Thus, AMs can not only induce, but also actively suppress T-cell activation and proliferation in health [12], and during inflammatory states [13].

Overall, little information is available on the precise role of AMs in promoting and regulating the inflammatory response to inhaled allergen that ultimately leads to the asthmatic attack. In the present study, we investigate the influence of AMs obtained from atopic asthmatics and nonasthmatic atopic healthy subjects on $\mathrm{T}$-cell proliferative responses, in the context of in vitro exposure to relevant and nonrelevant allergens.

\section{Material and methods}

\section{Subjects}

Twelve patients with atopic asthma were recruited, all were nonsmokers, 8 females and 4 males, mean \pm sem age $27 \pm 3$ yrs. Bronchial asthma was diagnosed by clinical history and confirmed by measurement of airways obst-

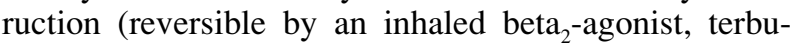
taline), and bronchial responsiveness to methacholine challenge (mean log provocative concentration of methacholine producing a $20 \%$ fall in forced expiratory volume in one second $\left.\left(\mathrm{PC}_{20}\right) 0.27 \pm 0.02 \mathrm{mg} \cdot \mathrm{ml}^{-1}\right)$. These patients were free of symptoms at the time of the study, had a resting forced expiratory volume in one second $\left(\mathrm{FEV}_{1}\right)$ of $74 \pm 8.6 \%$ predicted, and had not suffered any acute attacks in the preceding 3 months. Seven of the 12 patients were taking inhaled beta $_{2}$-agonists only; these patients were asked to stop their medication at least one day before bronchoscopy. The remaining five patients were "newly diagnosed" asthmatics, who had not previously received any form of medication. None of the 12 asthmatics was receiving any immunosuppressive or other therapy (inhaled or oral).

Atopy was defined by clinical symptoms, a cutaneous wheal response of $>5 \mathrm{~mm}$ diameter to at least two of the following aeroallergens (house dust, house dust mite, grass and tree pollens, cat fur and dog hairs, and Aspergillus fumigatus), high total immunoglobulin $\mathrm{E}(\mathrm{IgE})$ levels $\left(281 \pm 7.5 \mathrm{IU} \cdot \mathrm{ml}^{-1}\right)$ (paper disk radioimmunoassay technique, Pharmacia Laboratories; normal $<100 \mathrm{IU} \cdot \mathrm{ml}^{-1}$ ), and positive specific serum IgE antibodies (radioallergosorbent test (RAST), Pharmacia Laboratories).

The control populations consisted of: 1) six nonasthmatic atopic subjects (4 males and 2 females; $28 \pm 2$ yrs), who had seasonal symptoms of rhinitis, itchy eyes and/or eczema (mean IgE $165 \pm 9.0 \mathrm{IU} \cdot \mathrm{ml}^{-1}$ ), but were not on any current medication (including immunosuppressants); and 2) six nonatopic normal volunteers, who had no history of asthma or atopy ( 3 males and 3 females; $29 \pm 3$ yrs; negative skin prick tests; mean IgE $65.0 \pm 2.3$ $\left.\mathrm{IU} \cdot \mathrm{ml}^{-1}\right)$. All control subjects were nonsmokers with normal pulmonary function tests, and did not reach a $\mathrm{PC}_{20}$ on methacholine challenge; none had suffered from any viral illness in the two weeks preceding the study. Formal written consent was obtained from all subjects recruited; the study had received prior approval by the local Ethics Committee.

\section{Bronchoalveolar lavage (BAL)}

BAL was performed using a $6 \mathrm{~mm}$ fibreoptic flexible bronchoscope (Olympus BT-IT20D; Olympus Corp., UK). All subjects were premedicated with intravenous $0.6 \mathrm{mg}$ of atropine sulphate and $2-5 \mathrm{mg}$ midazolam (Hypnovel), as required, $15 \mathrm{~min}$ prior to the procedure. After local anaesthesia with 2\% lignocaine, the right middle lobe was lavaged with successive $20 \mathrm{ml}$ aliquots of sterile buffered $0.9 \%$ isotonic saline to a total volume of $180 \mathrm{ml}$. The lavage fluid was gently aspirated after each aliquot, and collected into a sterile siliconized glass bottle maintained at $4^{\circ} \mathrm{C}$.

\section{Processing of BAL samples}

The lavage fluid was filtered through a single layer of coarse gauze and centrifuged at $480 \times \mathrm{g}$ at $4^{\circ} \mathrm{C}$ for 5 min. The cell pellet was then washed twice in RPMI 1640 medium (Flow Laboratories, Paisley, Scotland), after which the cells were counted in a modified Neubauer haemocytometer and viability assessed by cellular exclusion of trypan blue. The final cell concentration in each sample was adjusted to $1 \times 10^{6}$ cells $\cdot \mathrm{ml}^{-1}$ using supplemented RPMI 1640, containing $1.25 \% 200 \mathrm{mM}$ L-glutamine, $10 \%$ autologous human serum, $100 \mu \mathrm{g} \cdot \mathrm{ml}^{-1}$ streptomycin and $100 \mathrm{IU} \cdot \mathrm{ml}^{-1}$ penicillin.

\section{Separation of BAL cells}

The above cell suspension was plated onto sterile plastic $85 \mathrm{~mm}$ diameter tissue culture grade Petri dishes (Nunc, Denmark), with a total of $4-6 \times 10^{6}$ cells on each and a medium suspension depth of $3 \mathrm{~mm}$. These were incubated for $2 \mathrm{~h}$ at $37^{\circ} \mathrm{C}$ in an atmosphere of $5 \%$ humidified $\mathrm{CO}_{2}$. The supernatant containing the nonadherent cell population was then collected, and the plate washed three times with medium to remove any further nonadherent cells. The adherent cells were gently scraped off the plates using a sterile "rubber policeman". The adherent and nonadherent cell populations were centrifuged at $480 \times \mathrm{g}, 4^{\circ} \mathrm{C}$ for $5 \mathrm{~min}$, resuspended in medium at $1 \times 10^{5}$ cells $\cdot \mathrm{ml}^{-1}$, and kept on ice until required.

\section{Cytospin preparation}

Cytospins were prepared on a Shandon Cytospin 2 using $2 \times 10^{4}$ cells in $100 \mu \mathrm{l}$ aliquots of each of the above cell suspensions. One cytospin from each sample was stained for morphology, whilst the remainder were air-dried for one hour at room temperature, fixed in a 1:1 mixture of chloroform-acetone for $10 \mathrm{~min}$, wrapped in plastic film and stored at $-20^{\circ} \mathrm{C}$ until use.

Cell morphology was determined using a Diff-Quik (Dade Diagnostics, UK) differential white cell stain. 


\section{Immunocytological analysis}

Macrophage phenotype in both adherent and nonadherent lavage cell samples was determined by two monoclonal antibodies EBM11 (which identifies all cells of the monocyte-macrophage lineage; Dakopatts, Denmark), and UCHM1 (which identifies antigen present on the majority of blood monocytes; P. Beverley, London, UK). The proportion of AMs expressing human leucocyte antigen-DR (HLA-DR) was investigated in both cell fractions, using a mouse immunoglobulin G (IgG) anti-HLA-DR monoclonal antibody (BectonDickinson, UK). A standardized immunoperoxidase technique was used [14].

\section{Peripheral blood mononuclear cells (PBMC)}

All subjects had $20 \mathrm{ml}$ of peripheral blood taken by venepuncture at the same time as the BAL. PBMC were separated on a Ficoll-Hypaque gradient, washed twice in Hank's balanced salt solution, and then resuspended in supplemented RPMI 1640. The PBMC suspension was counted and viability assessed. Plastic plate adherence was carried out, as with the lavage cells above; the separated PBMC cell fractions obtained were adjusted to a final cell concentration of $1 \times 10^{5}$ cells $\cdot \mathrm{ml}^{-1}$.

\section{Cell cultures}

All cultures (a-d) described below were set up in triplicate in flat-bottomed microtitre wells, and incubated at $37^{\circ} \mathrm{C}$ in an atmosphere of $5 \%$ humidified $\mathrm{CO}_{2}$ for 6 days. Equal volumes of supernatant $(50 \mu \mathrm{l})$ were gently aspirated from each culture without disturbing the cell pellet, and replaced with an equivalent amount of fresh supplemented RPMI prior to pulsing with $1 \mu \mathrm{Ci}$ ${ }^{3} \mathrm{H}$-thymidine ( ${ }^{3} \mathrm{H}-\mathrm{Tdr}$ ) (Amersham, UK; $5 \mathrm{Ci} \cdot \mathrm{mmol}^{-1}$ ). The cells were then incubated for a further $6 \mathrm{~h}$, and harvested using a semi-automatic cell-harvester (TitertekFlow, Laboratory Inc., Mclean, VA, USA). The amount of incorporated radioactivity was measured in a liquid scintillation counter, and expressed as average counts per minute $(\mathrm{cpm})$ of triplicate cultures. Blank wells consistently gave recordings of less than $40 \mathrm{cpm}$. The culture supernatants collected were stored at $-70^{\circ} \mathrm{C}$ until further use.

The culture experiments were set up as follows:

a) BAL cell cultures. Isolated plastic adherent and nonadherent BAL cells from six asthmatic atopic and six normal nonatopic recruits were cultured on their own and readmixed using a fixed 1:10 adherent:non-adherent cell ratio $\left(1 \times 10^{3}\right.$ adherent and $1 \times 10^{4}$ nonadherent cells in each well).

b) Response to mitogen. In other cultures, nonadherent PBMC $\left(1 \times 10^{4}\right)$ were stimulated with the T-cell mitogen phytohaemagglutinin (PHA) at the recommended concentration of $2.5 \mu \mathrm{g} \cdot$ well $^{-1}$ (PHA-P, Difco Laboratories); autologous adherent BAL cells $\left(1 \times 10^{3}\right)$ were added to some of these cultures. c) Response to allergen. In other experiments, control and allergen-treated cultures of adherent and nonadherent BAL cells and PBMC from six other asthmatic atopic and six nonasthmatic symptomatic atopic recruits were set up as above. Cultures of adherent BAL cells $\left(1 \times 10^{3}\right)$ with autologous nonadherent $\left(1 \times 10^{4}\right)$ and adherent $\left(1 \times 10^{3}\right)$ PBMC with or without allergen were also set up. Allergen sensitivity of each subject was determined at the time of recruitment (q.v. above). Doseresponse studies for each allergen suspension had been determined in previous experiments (data not shown); the allergen concentration giving the maximum proliferative response was chosen for stimulating the cell cultures in this study (grass pollen $1 \times 10^{4} \mathrm{U} \cdot \mathrm{ml}^{-1}$; house dust mite $1 \times 10^{4} \mathrm{U} \cdot \mathrm{ml}^{-1}$; cat fur $1 \times 10^{4} \mathrm{U} \cdot \mathrm{ml}^{-1}$; Aspergillus fumigatus $3 \mu \mathrm{g} \cdot \mathrm{ml}^{-1}$ ).

d) Effect of culture supernatants. In a separate set of experiments, nonadherent $\left(1 \times 10^{4}\right.$ cells $\cdot$ well $\left.^{-1}\right)$ and adherent $\left(1 \times 10^{3}\right.$ cells $\cdot$ well $\left.^{-1}\right)$ PBMC obtained from a nonsmoking, nonasthmatic, atopic subject were cultured alone, and in the presence of $100 \mu \mathrm{l}$ of supernatant collected from the above unstimulated and allergen-stimulated cell cultures of four asthmatic and four nonasthmatic atopic recruits.

\section{Measurement of prostaglandins}

Prostaglandin $\mathrm{E}_{2}\left(\mathrm{PGE}_{2}\right)$ and the stable product of prostaglandin $\mathrm{I}_{2}\left(\mathrm{PGI}_{2}\right)$ (6-oxo-PGF ${ }_{1}$ ) were measured in supernatants obtained from asthmatic nonadherent and adherent BAL cells, and co-cultures of adherent BAL cells and autologous nonadherent PBMC, using previously validated and well-established radio-immunoassay techniques [15]. Due to the high specificity and lack of interference of culture medium, no prior extraction and purification was required. The lower limit of prostaglandin detection in these assays was $5 \mathrm{pg}$. Antisera against $\mathrm{PGE}_{2}$ and prostaglandin $\mathrm{F}_{1}\left(\mathrm{PGF}_{1}\right)$ of high specificity were purchased from Capell Laboratories (West Chester, $\mathrm{PA}$, USA). ${ }^{3} \mathrm{H}_{-} \mathrm{PGE}_{2}\left(120 \mathrm{Ci} \cdot \mathrm{mmol}^{-1}\right)$ and $\mathrm{PGF}_{1}$ were purchased from New England Nuclear (Dreieich, West Germany), and unlabelled ligand from Cayman Chemical Co. ( Palo Alto, CA, USA).

\section{Statistical analysis}

The results are expressed as the mean \pm SEM. Significance between results was determined using Wilcoxon's test or the Mann-Whitney U-test. A probability value of $\leq 0.05$ was taken to indicate statistical significance.

\section{Results}

\section{Bronchoalveolar lavage cell recovery}

The percentage return of the total lavage fluid instilled was $69 \pm 7.4 \%$ in the asthmatic group, $72 \pm 4.3 \%$ in the 
nonasthmatic atopics, and $73 \pm 9.6 \%$ in normal subjects. The total BAL cell yield in the normal and nonasthmatic atopic volunteers was $9.7 \pm 1.1 \times 10^{6}$ cells (absolute number of AMs $9.2 \pm 1.1 \times 10^{6}$ cells) and $9.1 \pm 0.8 \times 10^{6}$ cells (absolute number of AMs $8.3 \pm 0.7 \times 10^{6}$ cells), respectively. The total BAL cell yield in asthmatic patients was $8.2 \pm 1.2 \times 10^{6}$, of which the absolute number of AMs was $7.0 \pm 0.9 \times 10^{6}$. The mean proportion of lymphocytes in asthmatic BAL was $10.2 \pm 5.1 \%$, compared to $5.6 \pm 3.2 \%$ and $4 \pm 3.5 \%$, respectively, in normal and symptomatic atopic lavage. The eosinophil count was higher $(\mathrm{p}<0.01)$ in the asthmatic patients $(4.6 \pm 1.1 \%)$ than in the normal $(<1 \%)$ and nonasthmatic symptomatic atopic $(1.3 \pm 0.2 \%)$ groups.

The viability of all lavage cells throughout all experiments was persistently $>90 \%$ by trypan blue exclusion. In all groups, plastic adherent cells from both BAL and PBMC were $>95 \%$ monocytoid in morphology. Adherent lavage cell samples were $>97 \%$ EBM11 positive but $<1 \%$ UCHM1 positive; nonadherent lavage cells were $<3 \%$ EBM11 positive and $<1 \%$ UCHM1 positive. Over $90 \%$ of alveolar macrophages were HLA-DR positive, with no significant differences amongst the three subject populations.

\section{Cell cultures}

a) BAL cell cultures. The endogenous reactivity of nonadherent and adherent lavage cells from asthmatics was significantly higher than in normals $(\mathrm{p}<0.0001)$ (fig. 1). In the asthmatic group, nonadherent BAL proliferation was suppressed from $2,100 \pm 98 \mathrm{cpm}{ }^{3} \mathrm{H}$-Tdr uptake to $1,118 \pm 53 \mathrm{cpm}(\mathrm{p}<0.0001)$ on admixture with autologous adherent lavage cells; this reaction was not apparent in the normal group (fig. 1).

b) Response to mitogen. Unstimulated nonadherent PBMC proliferation was higher in the asthmatic group $(\mathrm{p}<0.0001)$ (fig. 2). In both test groups, addition of adherent lavage cells to PHA-stimulated autologous nonadherent PBMC produced a reduction in thymidine incorporation (fig. 2). This suppression was more pronounced with asthmatic adherent lavage cells (109\%) compared to normal (76\%) (calculated as a percentage of the initial PHA-induced proliferation of $\mathrm{PBMC})(\mathrm{p}<0.0001)$ (fig. 2$)$.

c) Response to allergen. In separate experiments, we compared the effects of adherent BAL cells from six atopic asthmatics on the proliferative responses of autologous readmixed nonadherent and adherent PBMC cultured: 1) with allergen to which the patient was reactive; 2) with allergen to which the patient had no skin test or RAST reactivity; and 3) without any allergen. Similar control cultures were set up with cells from six nonasthmatic symptomatic atopic recruits.

In both groups, addition of adherent BAL cells suppressed the spontaneous proliferation of unstimulated PBMC (fig. 3a and b). In both groups, stimulation with relevant allergen increased autologous PBMC

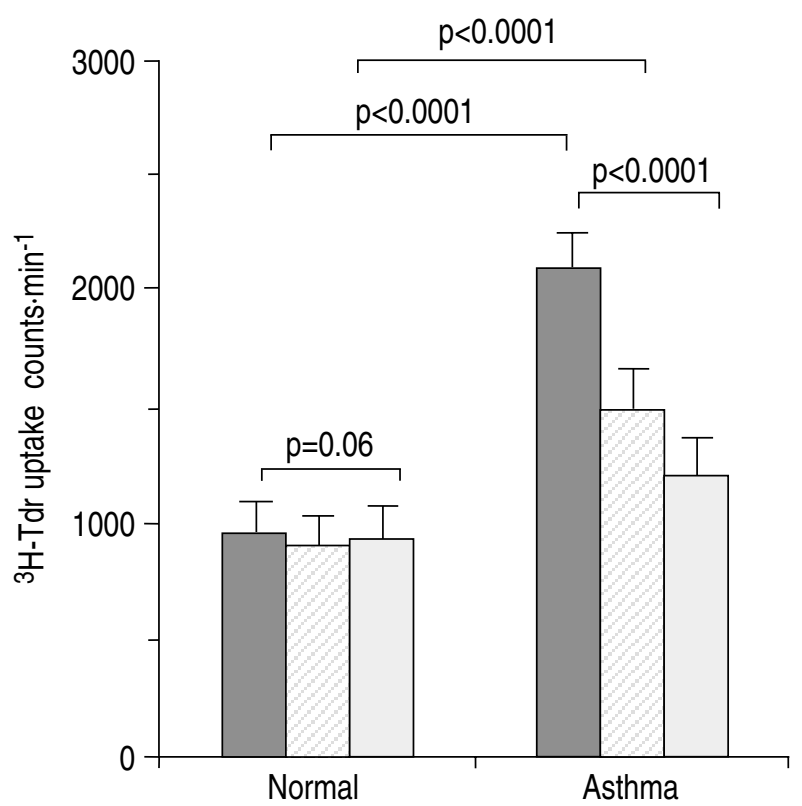

Fig. 1 - The proliferation of nonadherent BAL cells alone ( $\square$ ), adherent BAL cells alone ( $\square$ ), and readmixed adherent and nonadherent BAL cells $(\square)$ from normal controls $(n=6)$ and atopic asthmatics $(n=6)$. All cultures were incubated for 6 days, with ${ }^{3} \mathrm{H}-\mathrm{Tdr}$ incorporation measured over the last $6 \mathrm{~h}$. Each bar indicates the results of mean \pm SEM incorporated ${ }^{3} \mathrm{H}-\mathrm{Tdr}$ in counts. $\mathrm{min}^{-1}$. BAL: bronchoalveolar lavage.

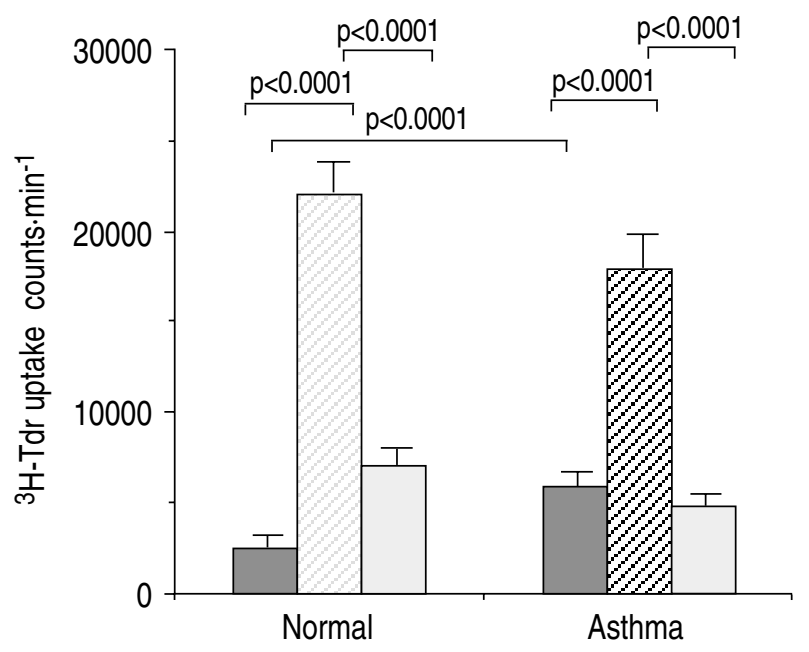

Fig. 2. - The effect of T-cell mitogen phytohaemagglutinin (PHA$\left.\mathrm{P}, 2.5 \mu \mathrm{g} \cdot \mathrm{well}^{-1}\right)$ on the proliferation of nonadherent peripheral blood mononuclear cells (NonAdh PBMC, $1 \times 10^{4}$ cells $\cdot$ well ${ }^{-1}$ ) is tested in the presence and absence of added adherent bronchoalveolar lavage (BAL) cells $\left(\right.$ AdhBAL, $1 \times 10^{3}$ cells $\cdot$ well $\left.^{-1}\right)$. All cultures were incubated for 6 days, with ${ }^{3} \mathrm{H}-\mathrm{Tdr}$ incorporation measured over the last $6 \mathrm{~h}$. Each bar indicates the results of mean \pm SEM incorporated ${ }^{3} \mathrm{H}-\mathrm{Tdr}$ in counts. $\mathrm{min}^{-1}$ for six normal subjects and six atopic asthmatic patients. $\square$ : NonAdh PBMC; $\square$ : NonAdh PBMC + PHA; $\square$ : NonAdh PBMC + PHA + AdhBAL.

proliferation. However, in the asthmatic but not in the nonasthmatic atopic subjects, the presence of adherent BAL cells in PBMC cultures stimulated with the allergen to which the patients were reactive resulted in enhanced PBMC proliferation by a mean of eight-fold 
a)

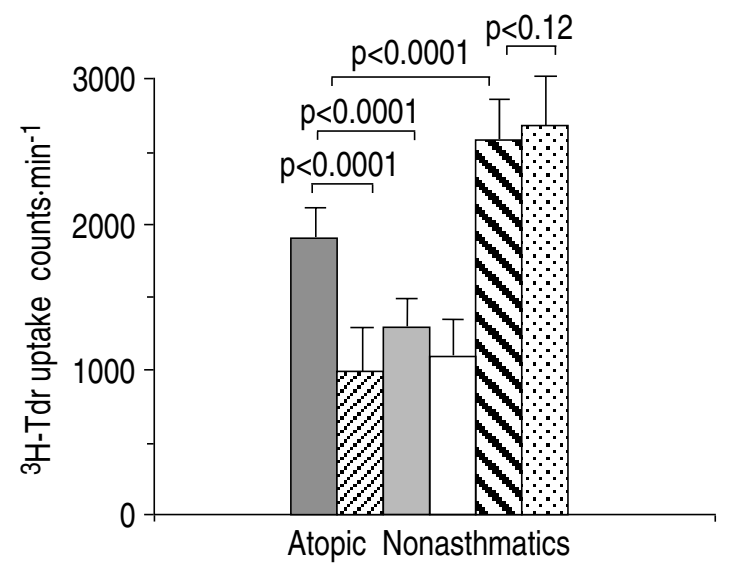

b)

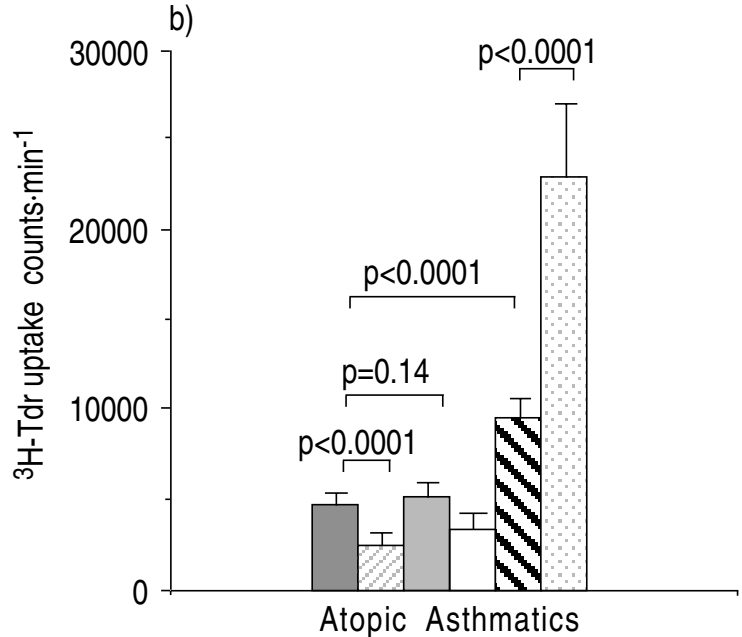

Fig. 3. - The effect of allergen to which the patient was skin and radioallergosorbent test (RAST) reactive (in this case grass pollen), and irrelevant allergen (negative skin and RAST reactivity, in this case Aspergillus fumigatus) on the proliferation of readmixed nonadherent and adherent peripheral blood mononuclear cells (PBMC) is tested in the presence and absence of adherent bronchoalveolar lavage (BAL) cells (AdhBAL). The final concentration of grass pollen used was $1 \times 10^{4} \mathrm{U} \cdot \mathrm{ml}^{-1}$, and that of Aspergillus fumigatus $3 \mu \mathrm{gg} \cdot \mathrm{ml}^{-1}$. All cultures were incubated for 6 days, with ${ }^{3} \mathrm{H}-\mathrm{Tdr}$ incorporation measured over the last $6 \mathrm{~h}$. Each bar indicates the results of mean \pm SEM incorporated ${ }^{3} \mathrm{H}-\mathrm{Tdr}$ in counts.min ${ }^{-1}$ for: a) six nonasthmatic atopic patients; and b) six asthmatic atopic patients. Please note the different scales in each figure. $\square$ PBMC; $\square$ : PBMC + AdhBAL; $\square:$ PBMC + A. fumigatus; $\square:$ PBMC + A. fumigatus + AdhBAL; $\square:$ PBMC + grass; $\square:$ PBMC + grass + AdhBAL.

a) Grass pollen

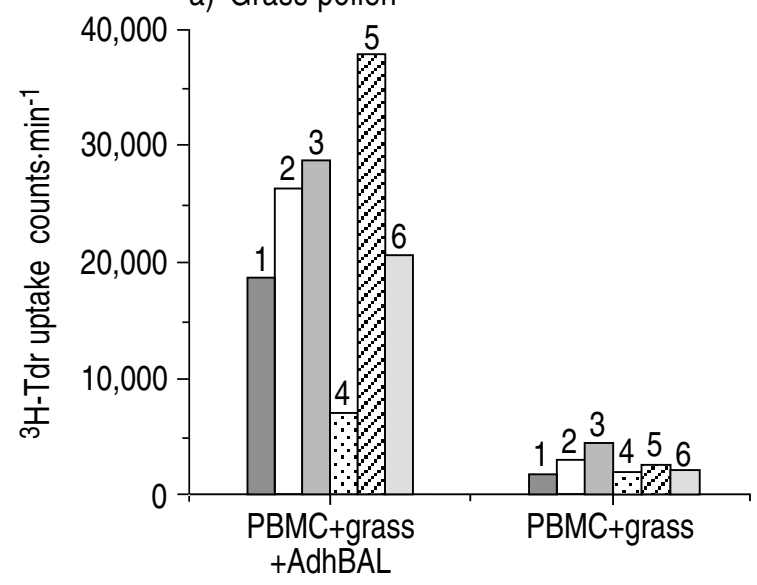

c) Cat fur

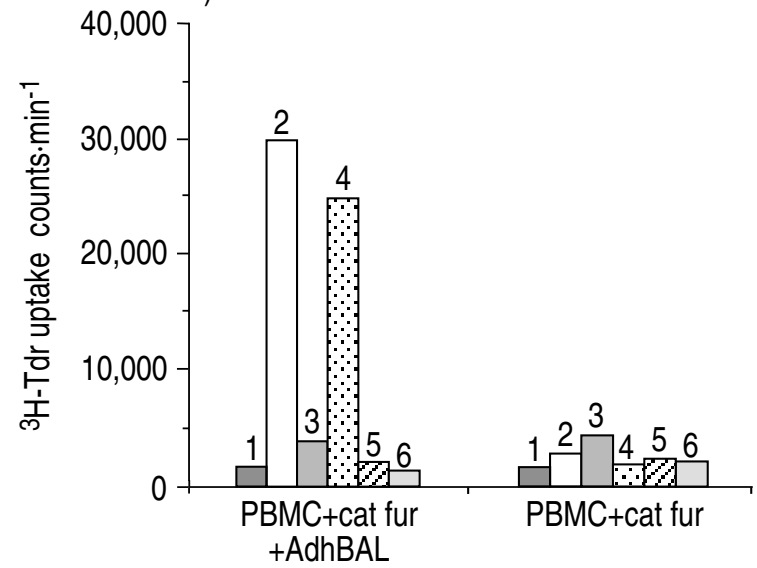

b) House dust mite

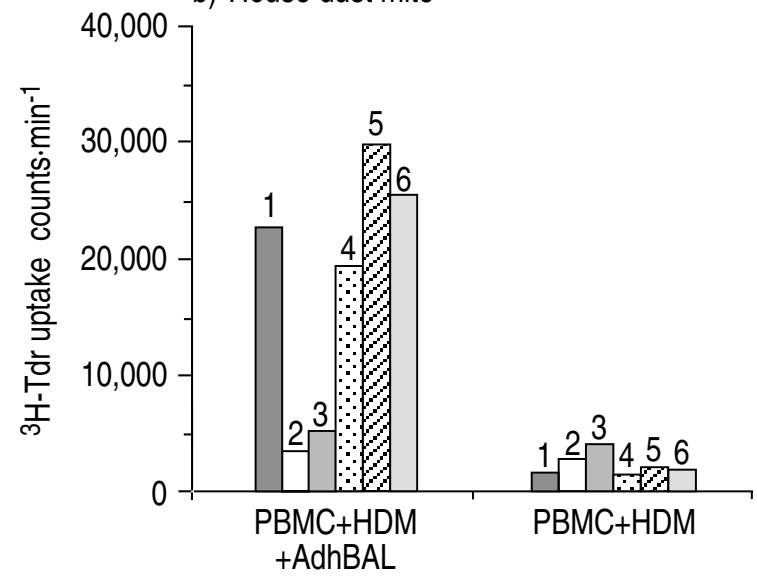

d) A. fumigatus

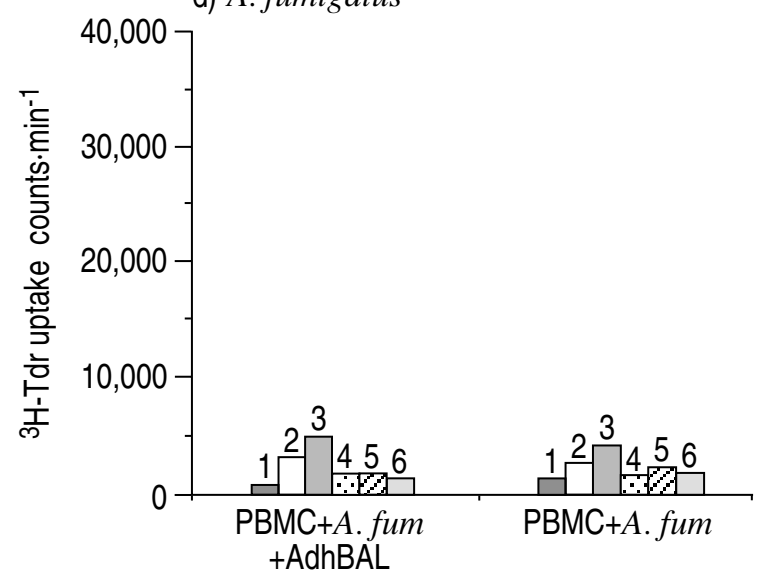

Fig. 4. - The effect of allergen to which the patient was skin and RAST reactive, and irrelevant allergen (negative skin and RAST reactivity) on the proliferation of readmixed nonadherent and adherent peripheral blood mononuclear cells (PBMC) in the presence and absence of adherent BAL cells (AdhBAL) is shown for each of the six atopic asthmatic subjects. Each bar indicates the results of incorporated ${ }^{3} \mathrm{H}-\mathrm{Tdr}$ in counts.min ${ }^{-1}$ for each culture for a single patient (subject number above bar). All cultures were incubated for 6 days, with ${ }^{3} \mathrm{H}-\mathrm{Tdr}$ incorporation measured over the last $6 \mathrm{~h}$. The final concentration of grass pollen used was $1 \times 10^{4} \mathrm{U} \cdot \mathrm{ml}^{-1}$, house dust mite (HDM) $1 \times 10^{4} \mathrm{U} \cdot \mathrm{ml}^{-1}$, cat fur $1 \times 10^{4} \cdot \mathrm{ml}^{-1}$, and Aspergillus fumigatus (A. fum) $3 \mu \mathrm{g} \cdot \mathrm{ml}^{-1}$. For abbreviations see legend to figure 3 . This figure should be analysed in association with table 1 . 
(from $3398 \pm 112$ to $23002 \pm 3650 \mathrm{cpm}$ ). This proliferation was more than double that observed in relevant allergen-treated PBMC cultures without adherent BAL cells $(p<0.0001)$ (fig. 3b). In the nonasthmatic group the presence of adherent BAL cells made no difference to relevant allergen-driven PBMC proliferation $(\mathrm{p}<0.12)$ (fig. 3a). The dramatic enhancing effect on contact with allergen to which the asthmatic was skin test and RAST reactive was seen consistently in all six asthmatic patients, but not with irrelevant allergen (table 1 , and fig. $4 \mathrm{a}-\mathrm{d}$ ). Interestingly, this reaction to relevant allergen was not observed in stimulated asthmatic nonadherent and adherent BAL cultures in the absence of PBMC (data not shown).

Table 1. - Allergen reactivity of asthmatic subjects as studied by cutaneous wheal response and RAST analysis

\begin{tabular}{ccccc}
\hline Subject & \multicolumn{5}{c}{ Allergen tested } \\
\cline { 2 - 5 } No. & Grass & $\begin{array}{c}\text { House dust } \\
\text { mite }\end{array}$ & $\begin{array}{c}\text { Cat } \\
\text { fur }\end{array}$ & $\begin{array}{c}\text { Aspergillus } \\
\text { fumigatus }\end{array}$ \\
\hline 1 & + & + & - & - \\
2 & + & - & + & - \\
3 & + & - & - & - \\
4 & + & + & + & - \\
5 & + & + & - & - \\
6 & + & + & - & - \\
\hline
\end{tabular}

RAST: radioallergosorbent test; +: relevant; -: irrelevant.

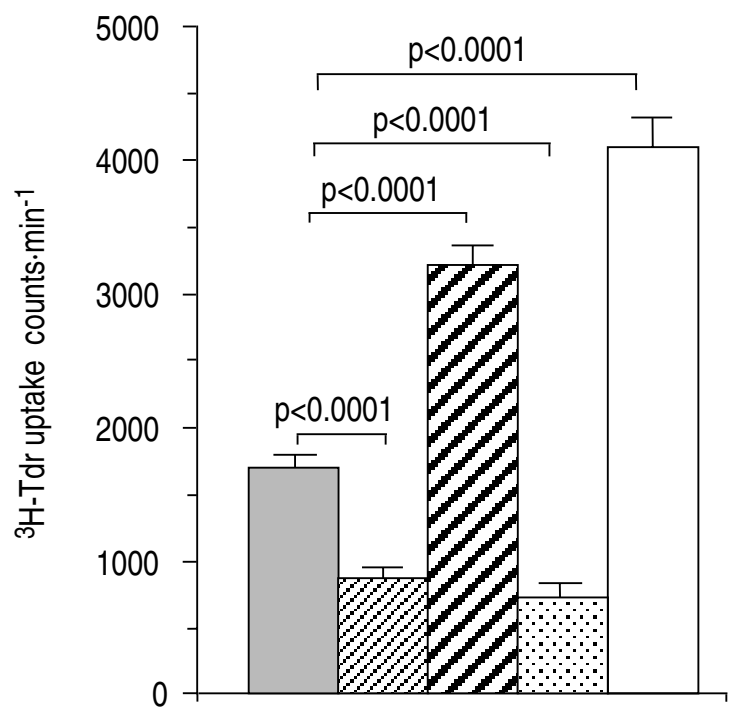

Fig. 5. - The effect of supernatants (Sup) from allergen (Ag)stimulated and -unstimulated cultures of asthmatic adherent bronchiolar lavage (AdhBAL) cells on their own, and co-cultures of asthmatic adherent lavage and autologous peripheral blood mononuclear cells (AdhBAL+PBMC) on the proliferation of allogeneic peripheral blood mononuclear cells (AlloPBMC) from a nonsmoking normal subject. All cultures were incubated for 6 days, with ${ }^{3} \mathrm{H}-\mathrm{Tdr}$ incorporation measured over the last $6 \mathrm{~h}$. Each bar indicates the results of mean \pm SEM incorporated ${ }^{3} \mathrm{H}-\mathrm{Tdr}$ in counts. $\mathrm{min}^{-1}$ for four atopic asthmatic patients. As: asthmatic; Sup: supernatant. $\square$ : AlloPBMC; $\square$ : AlloPBMC + As (AdhBAL) sup; $\square$ : AlloPBMC + As (AdhBAL + Ag) sup; $\square:$ AlloPBMC + As (AdhBAL + PBMC) sup; $\square$ : Allo$\mathrm{PBMC}+\mathrm{As}(\mathrm{AdhBAL}+\mathrm{PBMC}+\mathrm{Ag})$ sup. d) Effect of culture supernatants. Supernatants from cultures of asthmatic adherent BAL cells on their own, and co-cultures of asthmatic adherent BAL cells and autologous nonadherent and adherent PBMC all suppressed proliferation of allogeneic normal non-adherent PBMC from $1,630 \pm 87$ to $856 \pm 54$ and $756 \pm 69 \mathrm{cpm}$, respectively, $(\mathrm{p}<0.0001)$ (fig. 5). However, when supernatants from equivalent cell cultures incubated with relevant allergen were used, a twofold increase in PBMC proliferation was observed (fig. 5). Supernatants from equivalent normal cell cultures had no effect on spontaneous ${ }^{3} \mathrm{H}-\mathrm{TdR}$ uptake.

\section{Prostaglandin analysis}

No $\mathrm{PGE}_{2}$ or $\mathrm{PGF}_{1}$ was detected in any of the supernatants obtained from asthmatic nonadherent and adherent BAL cells, and co-cultures of adherent BAL and autologous nonadherent PBMC. Positive controls set up with "prostaglandin-spiked" preparations all detected the presence of $\mathrm{PGE}_{2}$ or $\mathrm{PGF}_{1}$, as appropriate.

\section{Discussion}

In this study, we have demonstrated that nonadherent lavage cells from stable atopic asthmatic patients proliferate spontaneously more than the corresponding cell fraction from normal donors; and that this can be suppressed by readmixture with the adherent fraction, the majority of the cells being alveolar macrophages (AMs) as determined by morphological and phenotypic examination. This suppressive effect was also observed in asthmatic and control donors, when the AM fraction was added to autologous nonadherent PBMC stimulated in vitro by the mitogen PHA. However, when PBMC from asthmatic patients were cultured with the allergen to which the patient was clinically, as well as skin and RAST test reactive, addition of autologous AMs produced a large increase in cell proliferation in all subjects tested. Such responses did not occur in any of the nonasthmatic atopic controls, even with allergen to which they were reactive.

Several previous studies have shown that AMs from normal subjects have suppressive activity [16-18]. There is also evidence that under persistent antigen stimulation, such as in smokers [19], and in infective lung disease [20], AMs appear to be more potent suppressors than AMs from healthy subjects. These data suggest that chronic antigenic stimulation favours the expansion of a functionally suppressive AM subpopulation, although Aubas et al. [21] reported a dose-dependent modulating effect of AMs with decreased suppressor AM activity in asthmatics at certain AM to PBMC cell culture ratios. Supportive evidence for our hypothesis is obtained from recent studies on sarcoid patients, that clearly show the emergence of functional suppressor macrophages within the AM population in proportion to the disease activity $[13,22]$. Functional reconstitution experiments performed in vitro show that, whatever the 
cell numbers used, these isolated AMs actively downregulate the induction of T-cell responses set up by other stimulator macrophages $[12,13]$. These observations are also supported in animal models [23].

Our study demonstrates that the endogenous reactivity of isolated adherent BAL cells from asthmatics is higher than equivalent normal cells (fig. 1). This observation could reflect a higher "state of intrinsic activation" within the macrophage population in the asthmatic lung [24, 25]. The increased spontaneous proliferation of AM-depleted BAL cells from asthmatics (fig. 1) would be consistent with a chronic inflammatory response occurring in the lungs of asthmatic patients. Interestingly, readmixture with autologous AMs (despite their increased intrinsic activation) reduces both this proliferation and that induced by mitogen. It is, thus, not inconceivable to suggest the existence of an in situ control for local T-cell responses within the asthmatic lung, in which the heterogeneity of AM accessory cell function may be important.

It has been suggested that suppression by AMs is mediated by soluble factors, such as prostaglandins [26]. In this present study, although AM supernatants suppressed PBMC proliferation (fig. 5) we were unable to detect any $\mathrm{PGE}_{2}$ and $\mathrm{PGF}_{1}$, raising the possibility that other soluble suppressor factors could be involved. In separate studies, we have found that AMs from stable asthmatics spontaneously release sizeable amounts of tumour necrosis factor- $\alpha$, a mediator known to inhibit T-cell proliferation [27]. This would not preclude a contribution by other inhibitory mediators within the inflammatory cocktail in the asthmatic lung.

Peripheral blood mononuclear cells from asthmatic patients showed small proliferative responses to those allergens to which they were skin test and RAST-reactive, as has been reported elsewhere. However, addition of autologous AMs, rather than suppressing these reactions, resulted in a marked increase in PBMC proliferation. This effect was not observed with AMs from nonasthmatic atopic subjects. Alveolar macrophages are known to be able to present antigens, although there are differences in antigen presenting capacity between AMs and circulating monocytes, which may reflect differences in glycosylation of major histocompatibility complex (MHC) Class II molecules [28]. The apparent selectivity of the enhancing effect seen in atopic asthmatics, but not in nonasthmatic atopics, for the clinically relevant allergens suggests that asthmatic AMs are able to process those same allergens to a highly immunogenic form.

Nonasthmatic control atopics do not show similar stimulation to relevant allergen. This is clearly not due to underlying lack of reactivity to allergen by their PBMC (fig. 3). The results in the nonasthmatic atopic group could reflect the negative clinical expression of atopy in their lungs (symptoms were restricted to the skin, eyes or nose); in addition, they had no evidence of airway hyperreactivity as judged by methacholine challenge.

It is interesting that the enhancing effect of asthmatic AMs was only seen with circulating PBMC but not with lavage lymphocytes. The lack of response with lavage lymphocytes may reflect the fact that all our asthmatic patients suffered from seasonal or "contact" asthma, but were studied at times when natural airborne allergen concentrations were low. Moreover, none had experienced an acute asthmatic episode within the preceding 3 months. In other studies, it has been noted that influenza-reactive cells disappear transiently from the blood following influenza immunization, an effect interpreted as being due to the selective localization of antigen-reactive cells at the site of antigen [29]. It may well be, therefore, that in asthma allergen-reactive cells migrate from the airway to the circulation at times when inhaled allergen concentrations are low. In support, sensitized T-cells are readily identified in the peripheral blood of atopic asthmatics, which following bronchial allergen challenge are actively recruited and selectively retained in the lung [30-32].

Evidence shows that functional heterogeneity within AMs may be reflected in cell phenotype and density [13, $33,34]$, which may alter with the onset and activity of disease. Chanez et al. [35] recently described a population of hypodense AMs in the lavage of stable asthmatic patients, distinct from the higher density AM fractions found in normal subjects. We have shown phenotypic differences between AMs from patients with active sarcoidosis and normal individuals [36]. Moreover, the phenotypic profile in sarcoidosis varies with disease activity [22], and is modified by corticosteroid therapy [37].

Whilst supernatants of allergen-pulsed AMs also enhanced PBMC proliferation, it is unclear whether this is due to carry-over of highly immunogenic processed allergen or to the production by pulsed AMs of immunoenhancing mediators. Studies on the cytokine profile produced by allergen-pulsed AMs are in progress.

Our observations argue against the suggestion of Aubus et al. [21] of "a general decreased functional activity" within the AM population in asthma. On the contrary, our study suggests that the asthmatic AM population may consist of a dynamic system of functionally suppressor and enhancer AM subpopulations, as demonstrated in other studies [12, 13], capable of serving as "accessory cells" to lung T-cells and modulating the nature of the lymphocyte response to aeroallergens. Future studies will focus on the identification of the specific features of these AM subpopulations in asthmatic patients; this could lead to specific targeting of therapy to the enhancer AM population, with abortion of induction of the cellular hypersensitivity cascade which leads to the clinical asthmatic reaction.

\section{References}

1. Holt PG, McMenamin C, Schon-Hegrad MA, et al. Immunoregulation of asthma: control of T-lymphocyte activation in the respiratory tract. Eur Respir J 1991; 4: $6-15$.

2. Godard P, Chantreuil J, Damon M, et al. Functional assessment of alveolar macrophages: comparison of cells from asthmatics and normal subjects. J Allergy Clin Immunol 1982; 70: 88-93.

3. Damon M, Chavis C, Crastes de Paulet A, Michel FB, 
Godard P. Arachidonic acid metabolism in alveolar macrophages. A comparison of cells from healthy subjects, allergic asthmatics and chronic bronchitis patients. Prostaglandins 1987; 34: 291-309.

4. Arnoux B, Joseph M, Simoes MH, et al. Antigenic release of PAF-acether and $\beta$-glucuronidase from alveolar macrophages of asthmatics. Bull Eur Physiopathol Respir 1987; 23: 119-224.

5. Djukanovic R, Lai CKW, Wilson JW, et al. Bronchial mucosal manifestations of atopy: a comparison of markers of inflammation between atopic asthmatics, atopic nonasthmatics and healthy controls. Eur Respir J 1992; 5: $538-544$.

6. Unanue ER, Allen PM. The basis for the immunoregulatory role of macrophages and other accessory cells. Science 1987; 236: 551-559.

7. Toews GB, Vial WC, Dunn MM, et al. The accessory cell function of human alveolar macrophages in specific T-cell proliferation. J Immunol 1984; 132: 181-186.

8. Takemura R, Weib Z. Secretory products of macrophages and their physiological functions. Am J Physiol 1984; 246: C1-C9.

9. Tonnel AB, Gosset P, Joseph M. Alveolar macrophage and its participation in the inflammatory processes of allergic asthma. Bull Eur Physiopathol Respir 1986; 22: 70-77.

10. Tonnel AB, Gosset P, Joseph M, Fournier E, Capron A. Stimulation of AM in asthmatic patients after local provocation test. Lancet 1983; i: 1406-1409.

11. Holt PG. Downregulation of immune responses in the lower respiratory tract: role of alveolar macrophages. Clin Exp Immunol 1985; 63: 261-270.

12. Spiteri MA, Poulter LW. Characterization of immune inducer and suppressor macrophages from the normal human lung. Clin Exp Immunol 1991; 83: 157-162.

13. Spiteri MA, Clarke SW, Poulter LW. Alveolar macrophages that suppress T-cell responsiveness may be crucial to the pathogenetic outcome of pulmonary sarcoidosis. Eur Respir J 1992; 5: 394-403.

14. Mason DY, Abdulaziz Z, Falini B, Stein H. Double immunoenzymatic labelling. In: J. Polak, $\mathrm{S}$ van Noorden, eds. Immunocytochemistry: Practical Applications in Pathology and Biology. Bristol, John Wright, 1983; pp. 113-117.

15. Jeremy JY, Mikhailidis DP, Dandona P. Muscarinic stimulation of rat tracheal prostanoid synthesis: calcium dependency and effect of corticosteroids and cigarette smoke. Eur J Pharmacol 1989; 160: 107-115.

16. Lipscomb MF, Lyons RC, Nunez G, et al. Human alveolar macrophages: HLA-DR positive macrophages that are poor stimulators of a primary mixed leukocyte reaction. J Immunol 1986; 136: 497-504.

17. Lyons RC, Ball EJ, Toews GB, Weissler JC, Stastny P, Lipscombe MF. Inability of human alveolar macrophages to stimulate resting T-cells correlates with decreased antigen-specific T-cell macrophage binding. J Immunol 1986; 137: 1173-1180.

18. McCombs CC, Michalski JP, Westerfield BT, Light RW Human alveolar macrophages suppress the proliferative response of peripheral blood lymphocytes. Chest 1982; 82: 266-271.

19. de Shazo RD, Banks DE, Diem JE, et al. Bronchoalveolar lavage cell-lymphocyte interactions in normal nonsmokers and smokers. Analysis with a novel system. Am Rev Respir Dis 1983; 127: 545-548.

20. Rich EA, Tweardy DJ, Fujiwara H, Ellner JJ. Spectrum of immunoregulatory functions and properties of human alveolar macrophages. Am Rev Respir Dis 1987; 136: 258-265.

21. Aubas P, Cosso B, Godard P, Michel FB, Clot J. Decreased suppressor cell activity of alveolar macrophages in bronchial asthma. Am Rev Respir Dis 1984; 130: 875-878.

22. Ainslie G, duBois RM, Poulter LW. Relationship between immunocytological features of bronchoalveolar lavage and clinical indices in sarcoidosis. Thorax 1989; 44: 501-509.

23. Holt PG, Degerbrodt A, O'Leary C, Krska K, Plozza T. $\mathrm{T}$-cell activation by antigen presenting cells from lung tissue digests; suppression by endogenous macrophages. Clin Exp Immunol 1985; 62: 586-593.

24. Joseph M, Tonnel AB, Torpier G, Capron A, Arnoux B, Benveniste $\mathrm{J}$. Involvement of immunoglobulin $\mathrm{E}$ in the secretory processes of alveolar macrophages from asthmatic patients. J Clin Invest 1983; 71: 221-230.

25. Rankin JA, Hitchcock M, Merril WW, Bach MK, Brashar JR, Askenase PW. IgE-dependent release of leukotriene $\mathrm{C}_{4}$ from alveolar macrophages. Nature 1982; 279: 329-331.

26. Demenkoff JH, Ansfeld MJ, Kaltreider HB, Adam E. Alveolar macrophage suppresson of canine bronchoalveolar lymphocytes: the role of prostaglandin $\mathrm{E}_{2}$ in the inhibition of mitogen response. J Immunol 1980; 124: 1365-1370.

27. Spiteri MA, Prior C, Herold M, Knight RA, Clarke SW, Chung KF. Profile of specific cytokine release from bronchoalveolar lavage cells in bronchial asthma: an enhancement of IL-1, IL-6, TNF-alpha, and GM-CSF. Am Rev Respir Dis 1992; 145: 239.

28. Ferro TJ, Monos DS, Spear BT, et al. Carbohydrate differences in HLA-DR molecules synthesized by AM and blood monocytes. Am Rev Respir Dis 1987; 135: 1340-1344.

29. Mitchell DM, Fitzharris P, Knight RA, Schild GC. Kinetics of specific in vitro antibody production following influenza immunization. Clin Exp Immunol 1982; 48: 491-497.

30. Gerblich AA, Campbell AE, Schuyler MR. Changes in T-lymphocyte subpopulations after antigenic bronchial provocation in asthmatics. N Engl J Med 1984; 310: 1349-1352.

31. Beasley R, Roche WR, Roberts JA, Holgate ST. Cellular events in the bronchi in mild asthma and after bronchial provocation. Am Rev Respir Dis 1989; 139: 806-817.

32. Kay AB. "Helper" CD4+ T-cells and eosinophils in allergy and asthma. Am Rev Respir Dis 1992; 145: 22-26.

33. Shellito J, Kaltreider HB. Heterogeneity of immunologic function among subfractions of normal rat alveolar macrophages. Am Rev Respir Dis 1984; 129: 747-753.

34. Brannen AL, Chandler DB. Alveolar macrophage subpopulations' responsiveness to chemotactic stimuli. Am J Pathol 1988; 132: 161-166.

35. Chanez P, Bousquet J, Couret I, et al. Increased numbers of hypodense alveolar macrophages in patients with bronchial asthma. Am Rev Respir Dis 1991; 144: 923-930.

36. Spiteri MA, Clarke SW, Poulter LW. Phenotypic and functional changes in alveolar macrophages contribute to the pathogenesis of pulmonary sarcoidosis. Clin Exp Immunol 1988; 74: 359-364.

37. Spiteri MA, Newman SP, Clarke SW, Poulter LW. Inhaled corticosteroids can modulate the immunopathogenesis of pulmonary sarcoidosis. Eur Respir J 1989; 2: 218-224. 